\title{
The great delusion of engagement: how China should compete with America
}

\author{
Tao Xie ${ }^{1}$
}

Received: 22 April 2020 / Accepted: 10 June 2020 / Published online: 24 June 2020

(c) The Institute of International and Strategic Studies (IISS), Peking University 2020

\begin{abstract}
Faced with a fundamental shift in America's China policy, Beijing should have a clear-eyed analysis of its choices and strategies. It is no longer feasible for China to hide its capabilities and bide its time. Instead, competition must be met with competition. Thus, China should rethink how to improve its competitive strength vis-à-vis the United States. Strength stems from not only economic and military power, but also international legitimacy. To bolster its international legitimacy, China should improve relations with its neighbors, enable the international community to have a larger share of its prosperity, articulate broadly appealing political values, and make its national identity more inclusive. These four steps are not confrontational, but they will make China a more formidable competitor vis-à-vis the United States.
\end{abstract}

Keywords China $\cdot$ America $\cdot$ Competition · International legitimacy

\section{Introduction}

The extraordinary rise of China can be attributed to many crucial factors, including its policy of reform and opening up, its massive pool of cheap labor, and its heavy investment in manufacturing and infrastructure. However, without active engagement by the United States, China's economic miracle certainly would have been delayed (or much less impressive). A cooperative relationship with America has allowed China to access western capital and technology, reap the enormous benefits of international free trade, and enjoy four decades of peace and security in its neighborhood. Since Richard Nixon's 1972 landmark visit, engagement with China has been the prevailing consensus in Washington, despite occasional setbacks and sporadic tensions in bilateral relations.

Tao Xie

xietao@bfsu.edu.cn

1 School of International Relations and Diplomacy, Beijing Foreign Studies University, Beijing, China 
Now a new consensus appears to be emerging among an increasing number of U.S. officials, analysts, and pundits, one that calls for replacing engagement with getting tough on China (Blackwill and Tellis 2015; Mead 2018; Shambaugh 2017; Zhao 2017). This new consensus grows out of the widespread perception that China has utterly failed to meet the underlying expectations of U.S. engagement, that is, that it would adopt liberal democracy, embrace market capitalism, and submit to U.S. leadership (Campbell and Ratner 2018). In other words, engagement is now widely viewed as nothing more than a great delusion, a wrong-headed conviction in America's ability to transform China and in China's amenability to American influence.

This new consensus was written into the Trump administration's 2017 National Security Strategy and 2018 National Defense Strategy, which labeled China "revisionist power" and "strategic competitor," respectively (White House 2017; U.S. Department of Defense 2018). On May 20, 2020, the White House (2020) released a report that outlines its "whole-of-government approach [to] strategic competition" with China. Meanwhile, charges and sanctions against Huawei, allegations of Chinese "sharp power," tightened visa restrictions on Chinese scholars and students, and the 18-month-long trade war, to mention the most notable examples, indicate a steady but unmistakable trend of America's "decoupling" from China (Johnson and Gramer 2020; National Endowment for Democracy 2017; U.S. Department of Commerce 2020; U.S. Department of Justice 2019).

Faced with this fundamental shift in America's China policy, Beijing should have a clear-eyed analysis of its choices and strategies. Strategic competition from the United States must be met with strategic competition. To compete, though, is not to confront. Competition with America does not necessarily mean an all-out arms race or a new Cold War (Wang 2018; Zhao 2019).

Instead, China must first improve its competitive strength via-a-vis the United States. Strength stems from not only economic and military power, but also international legitimacy (Lake 2018). To bolster its international legitimacy, Beijing should improve relations with its neighbors (periphery), provide the international community with broadly shared prosperity (performance), articulate a set of values that are uniquely Chinese but universally appealing (principle), and revamp its existing laws to allow foreign residents to be fully integrated into Chinese society (inclusiveness). These four steps are not confrontational, but they will make China a more formidable competitor vis-à-vis the United States.

\section{Better a neighbor nearby than a relative far away}

China is surrounded by 14 countries on land and shares border with another six by sea. No other country has a more complicated geopolitical endowment. Thus, how to maintain friendly relations with so many neighbors has been a top priority of Chinese foreign policy since 1949. Toward that goal Chinese leaders proposed the Five Principles of Peaceful Co-existence in 1953, which has since been the fundamental guideline in its neighborhood diplomacy. Since the 1990s Chinese leaders have 
repeatedly pledged to pursue a policy of building friendship and partnership with neighboring countries (e.g., Xi 2013).

Yet ironically, China's relations with quite a few of its neighbors have rarely been "good neighborly and friendly." It had border clashes with India (1962), the Soviet Union (1969), and Vietnam (1979). In addition to its unsettled border with India, China has outstanding maritime disputes with Japan, the Philippines, and Vietnam, and these disputes have led to sporadic standoffs in the East China Sea and the South China Sea. On the Korean Peninsula, Pyongyang's nuclear ambition has severely strained its relations with Beijing, notwithstanding Kim Jong-un's four visits to China since 2018. Despite booming bilateral trade and investment, Seoul's decision in 2017 to install Terminal High Altitude Area Defense (THAAD) plunged the bilateral relationship into an abyss, from which it has barely recovered.

China's fraught relations with these countries should not be interpreted, a priori, as evidence that its leader merely paid lip service to peaceful co-existence. Instead a strong case can be made that important differences in political institutions and values, historical legacies of China's relations with Japan, Vietnam, and the two Koreas, the convoluted China-India-Pakistan relationship, and extensive U.S. security alliance network in East Asia, among other factors, make it extremely difficult for China to build friendship and partnership with many of its neighbors.

This is not to say, however, that Beijing should give up trying to improve its neighborhood diplomacy and instead seek good relations with countries outside Asia. In international politics a country can choose its friends and enemies, but not its neighbors. Unfriendly and/or unstable neighbors threaten a country's national security, increase the costs of its interactions with those beyond its immediate neighborhood, and have the potential to disrupt its economic development. For the sake of national security and continued economic growth, it is better for Beijing to have friendly and stable neighbors in East Asia than to cultivate partners (or even allies) in Africa, Europe, or the Americas.

The road to better relations with many of China's neighbors must go through Tokyo. Chinese official discourse has portrayed the two countries as "close neighbors separated only by a strip of water," yet they are close only physically andsince the 1970s-economically. Because of Japanese aggression against China from the 1890s until the 1940s, the U.S.-Japan military alliance, and disputes over the Diaoyu Islands, Beijing and Tokyo have never been politically close.

Nevertheless, regardless of historical and contemporary sources of distrust and dispute, Japan is the world's third largest economy (second largest in Asia) and one of the closest allies of the United States. Besides, despite its invasion of Southeast Asia during World War II, Tokyo apparently has redeemed itself in the region through trade, investment, development assistance, and public diplomacy (Japan Center for International Exchange 2004; Llewelyn 2014; Sukma and Soeya 2015). Last but not least, Japan plays a pivotal role in the "free and open Indo-Pacific strategy" that calls for close cooperation among the Quad of Australia, India, Japan, and the United States (Ministry of Foreign Affairs of Japan 2019; U.S. Department of Defense 2019). In short, Japan is a vital gateway through which China can engage many countries in the Asia-Pacific and the Indo-Pacific. Beijing ignores the critical geopolitical role of Tokyo at its own peril. 
Since it takes two to tango, the outcome of any Chinese initiative to improve bilateral relations also depends on Japanese willingness to cooperate and reciprocate. Even if Tokyo fails to respond positively, such initiatives nevertheless put Beijing in a positive light. Above all, to reach out to Japan is not to sell out China, but rather to better serve its long-term interests. For China to counter America's intense strategic rivalry, a friendly and cooperative relationship with Japan is probably far more valuable than a partnership with any other country.

As the first step toward cultivating friendship and partnership with Japan, the Chinese president is well advised to pay a state visit to Tokyo at the earliest possible date. The last state visit by a Chinese president was in 2008. A state visit is a not a silver bullet for improving the complicated relationship, but it is surely a powerful signal of Beijing's commitment to doing so.

\section{Broadly shared economic prosperity}

The rise of China is first and foremost an economic miracle. For three decades its economy grew at an annual average of nearly $10 \%$, an unprecedented record for a major economy. Per capita GDP (in constant 2010 U.S. dollar) has increased by a factor of 20 since 1978 (World Bank 2018a, b). By 2011, China had already become the world's second largest economy (McCurry and Kollewe 2011). As a result of this breakneck growth, more than 850 million Chinese people have been lifted out of absolute poverty, an unparalleled achievement in human history (World Bank 2018b).

In the process of dramatically improving the livelihood of its own people, China also has significantly contributed to the prosperity of the rest. Its annual contribution to world economic growth averaged above 30\% in 2012-2017 (Xinhua News Agency 2018a). This contribution is most potently manifested in international trade. Between 2000 and 2012 China's share of world export and import growth was 15\% and $11.86 \%$, respectively, nearly twice that of the United States. At the end of 2012, it replaced the latter as the world's biggest trading nation (Reuters 2018). Total Chinese imports added up to a staggering \$13 trillion in 2000-2013, directly generating at least 100 million jobs worldwide (Zhang 2015). Today Beijing is the top trading partner of more than 100 countries (China.com.cn 2014). China has truly become the most powerful engine of global economic growth.

Nevertheless, China's dazzling economic performance apparently has produced much more legitimacy at home than abroad. A major controversy concerns its trading pattern with many developing countries. To drive the Chinese economic juggernaut requires an astronomical amount of commodities, such as energy resources, minerals, and primary agricultural products, which are concentrated in Africa and Latin America. Consequently, Chinese imports from those two continents have comprised primarily of commodities, while its exports almost exclusively manufactured products (Gamache et al. 2013). This has led to frequent charges of neocolonialism against China by both Western and local officials, journalists, and analysts (Dok and Thayer 2019; Su 2017). 
Admittedly, this trading pattern is probably not in the best interest of commodity-rich countries. For starters, Beijing's voracious demand has driven up commodity prices, which in turn has led to local economic boom, but this boom turned out to be short-lived in the wake of China's economic slowdown starting from 2014 (BBC News 2016; Egan 2015). Besides, surges in commodity prices often resulted in stronger local currencies, which made it more attractive to import manufactured products than to develop local manufacturing industries. Moreover, because natural resources are usually publicly owned and because resource extraction is capitalintensive rather than labor-intensive, commodity exports tend to enrich a small number of elites rather than bring about widespread benefits to local populations (Patrick 2012). Last but not the least, extractive activities often lead to long-term environmental damage, which likely outweigh their short-term benefits for local residents (Cote-Muñoz 2019).

Nevertheless, it would be absurd to hold China accountable for the so-called "commodity trap," for it has used neither force nor coercion in its economic relations with those countries. Instead, one can certainly argue that legacies of Western colonialism and structural disadvantages of late-developing countries notwithstanding, overdependence on commodity exports is largely a choice of local political leaders, who ultimately decide whether, what, and how much to sell to and buy from China. In the twenty-first century, a nation's economic fortunes are considerably shaped by the nature of its political institutions, i.e., whether they are inclusive or extractive, a point that has been forcefully argued by two economists (Acemoglu and Robinson 2012). If there is a commodity trap, it is a trap mostly set up by a country's political leaders, not by sinister schemes of foreign governments.

That being said, if Beijing wants to improve the economic dimension of its international legitimacy, it should think about ways that will allow developing countries to have a larger share of its prosperity. To be sure, China has provided an astronomical amount of foreign aid to numerous countries in Africa and Southeast Asia, but such aid-just like commodity exports-usually fails to generate widespread and sustainable economic benefits for local populations (The PRC State Council Information Office 2014). The ambitious Belt and Road Initiative, which was launched by Beijing in 2013 and is often called China's Marshall Plan, aims to boost economic development in the vast Eurasian continent primarily through massive infrastructure investment, but the benefits of such investment—as in the case of foreign aid and resource extraction-are generally short-lived and narrowly distributed. Besides, Chinese-financed infrastructure projects reportedly have caused some countries to fall into "debt trap," a charge that has led to local and international backlash against the Chinese initiative (Gerstel 2018; Lai et al. 2020).

To help developing countries achieve economic self-sufficiency and sustainable development, China should instead spend more efforts on capacity-building, such as vocational training, entrepreneurial incubation, and scholarship for advanced training in China (Xinhua News Agency 2018b). More importantly, Beijing should encourage and assist developing countries to build indigenous manufacturing capabilities, even though the Chinese development model that relies heavily on exports of manufactured products can hardly be replicated anywhere else. As a popular 
saying goes, "give a man a fish and you feed him for a day; teach a man to fish and you feed him for a lifetime."

To sum up, China's spectacular economic growth certainly has generated much admiration abroad, but such admiration would be short-lived if Beijing is perceived to have enriched itself at the cost of the rest. Here the United States offers a valuable lesson for Chinese leaders. By opening up its domestic market for foreign manufactured products and taking the lead in promoting free trade (as embodied in the World Trade Organization), the United States made its post-World War II economic boom broadly shared, which in turn greatly bolstered America's international legitimacy. Now that the world is facing probably the worst economic recession since 1929 due to the global pandemic caused by a new coronavirus (COVID-19), it is imperative that Beijing rethink its international economic practices and adopt policies that will help generate broadly shared prosperity in the international community.

\section{The soft power of political values}

Great power competition is not merely about tangible power like economic resources and military capabilities; it is also about intangible power like political values. During the Cold War, competition between the United States and the former Soviet Union involved not only military spending, economic production, and technological innovation, but also ideological struggle. Thus, the collapse of the Soviet Union was hailed not only as compelling evidence of America's superior hard power, but also as the decisive victory of American liberal democracy over alternative political ideologies, one that symbolized "the end of history" (Fukuyama 1992).

This intangible power of political values is also called soft power, which refers to "the ability to affect others to obtain the outcomes one wants through attraction rather than coercion or payment (Nye 2008)." More specifically, attraction means "the ability to shape the preferences of others" so that they will want what you want. In addition, the primary sources of attraction, according to Nye (2004), are culture, political values, and foreign policies. In a word, while hard power is coercive, softer power is seductive, but no less effective in getting what one wants.

Unsurprisingly, improving China's soft power has been a top priority of Chinese foreign policy since the 1990s. Beijing has invested billions of dollars to improve its international communication (or overseas publicity) capabilities. It has also funded hundreds of Confucius Institutes across six continents to promote its traditional culture: Chinese language, calligraphy, food, folk dance and music, traditional holidays, and Kung Fu (e.g., Xie and Page 2013). Meanwhile, high-speed train, Alibaba, online payment, and sharing economy - dubbed the new four great inventions of the Middle Kingdom - certainly have added a strong modern taste to China's cultural attractiveness.

When it comes to political values, however, China appears to have a huge deficit, especially compared with the United States, which has not only made democracy and human rights more or less universally accepted values, but also portrayed itself as the most powerful champion of these values. Thus, one of the biggest foreign policy challenges for Beijing is to propose and promote a set of political values that 
are closely associated with China and which can resonate with mass publics around the world.

Admittedly, the Chinese leadership has promulgated several important principles that ostensibly have strong international appeal, notably a harmonious world, a new type of major power relations, and a community of shared future for mankind. Nevertheless, these principles usually strike international observers as guidelines for Chinese foreign policy in particular and inter-state relations in general, rather than political values for individuals and governments to pursue.

There is one value, however, that has nearly unanimous support among the Chinese public and which has been practiced by the Chinese government with stunning success. That value can be summarized in one sentence: economic rights are the most fundamental human rights. At its most basic, economic rights mean freedom from poverty for individuals. As mentioned early on, China has lifted more than 800 million people out of absolute poverty within merely four decades. It also has committed itself to completely eliminating absolute poverty among its 1.4 billion people by the end of 2020 .

To be sure, a meaningful and dignified human life comprises of not only economic rights (e.g., the right to work), but also political rights (e.g., freedom of speech), yet the latter becomes meaningless when an individual's basic physical needs are not met. For those who are trapped in abject poverty or struggle to make the ends meet on a daily basis, freedom of speech probably matters much less than the right to a decent and stable income. To borrow the words of Franklin D. Roosevelt, freedom from want is no less important than freedom of speech, freedom of worship, or freedom from fear.

This explains why many Americans invoked the right to work in their protests against stay-at-home orders imposed by many state governments in response to the spread of COVID-19 (Sorace 2020). It also explains why economic rights are treated as an integral part of human rights by the United Nations and are enshrined in the International Covenant on Economic, Social and Cultural Rights. When the former candidate for the 2020 Democratic presidential nominee Bernie Sanders declared that "economic rights are human rights" in the wealthiest country in the twenty-first century, he was speaking a simple but universal truth, one that has long been recognized by the Chinese government but which unfortunately has been denied by most western elites.

In a word, economic rights are political rights. Without the former, the latter degenerates into the opium for the people. Human rights include not only those political rights set forth in the first ten amendments to the U.S. constitution (i.e., the Bill of Rights), but also economic rights championed by the United Nations. China has been an inspiring example of promoting economic rights at home and-to a lesser extent-abroad. The global economic recession caused by COVID-19-especially frequent protests in the United States for the right to work-has highlighted the fundamental flaws of defining human rights narrowly in terms of political rights. In the post-COVID-19 era, Beijing should have an easier time finding audiences abroad who are receptive to a new discourse on human rights. 


\section{A more inclusive Chinese identity}

China is a highly homogenous society, with $91.5 \%$ of its population being Han Chinese (National Bureau of Statistics of China 2011). Moreover, unlike residents of immigrant countries (e.g., America, Australia, and Canada), the overwhelming majority of the Chinese people are the descendants of the Yellow Emperor, and they have lived in the Middle Kingdom for thousands of years. As a result, cultural traditions and racial features of the Han are usually assumed to constitute the core of Chineseness: hieroglyph, ancestral worship, Confucianism, dark hair, dark eyes, and yellow skin.

When Chineseness (we) is so defined-or imagined-foreignness (they) becomes easily identifiable, especially when it comes to racial features. More importantly, for a number of reasons-historical and political-foreigners are greeted with a mix of varying degrees of curiosity, hospitality, suspicion, and deference, depending on where they come from and for what purposes. Regardless, they are all treated separately as a group, though not necessarily equally as their Chinese counterparts in terms of employment, healthcare, and education.

This special treatment of foreigners becomes highly problematic against the backdrop of China's growing economic prosperity and global influence, as more of them are coming to the Middle Kingdom in pursuit of jobs, business opportunities, advanced education, or even a different way of life. Some have applied to become permanent residents or naturalized citizens, but the existing Chinese laws only allow a negligible number of them to do so. In 2016, the Chinese government issued a total of 1576 green cards out of roughly one million foreign residents who were living in China (Beijing News 2017). Thus, the average foreigner may be treated nicely and deferentially, but she will most likely be a stranger in China, even if she has been thoroughly assimilated.

Yet to be a global power, China's extremely tight immigration laws must be reformed so as to make Chineseness more inclusive. Throughout history a defining feature of a global power-be it the Roman Empire or the British Empire-is its willingness to welcome and assimilate foreigners. An inclusive national identity not only makes China more attractive, but also more competitive, as foreigners can bring an immense amount of human and financial capital to bear on China's economic development, scientific research, and technological innovation.

The urgency of reforming China's immigration laws was not lost on the Chinese leadership. On April 2, 2018, the National Immigration Administration was established, the first of its kind in China's 5000-year-plus history and the first step toward a more inclusive Chinese national identity (Huang and Yan 2018; Zhang 2018). In early March of 2020 Beijing put forward a draft of regulations that aims to ease restrictions on permanent residence for foreigners. The strong online backlash against the draft regulations, however, clearly indicates that the vast majority of the Chinese populace is unwilling to grant national treatment to foreign residents (Giovannini 2020; Kharpal 2020).

Over the past four decades, millions of Chinese nationals have emigrated to foreign lands for various purposes. It is unfair at best and discriminatory at worst 
if foreign governments are expected to open their borders to Chinese immigrants but membership in the Chinese society is jealously guarded. Besides, just as Chinese immigrants have made important contributions to their adopted homelands, increased inflow of foreign nationals will surely bring important benefits to the Chinese society.

A global China requires a global Chinese identity, one that allows foreign nationals to be fully incorporated-if not assimilated-into the Chinese body politic. To work toward a community of shared future for mankind, the first step is to change China's immigrations laws so as to enable foreign nationals to seek their "Chinese Dream" and to be a stakeholder in China's future.

\section{Conclusion}

The global pandemic caused by COVID-19 has made the fraught China-U.S. relationship even worse. The Trump administration has shown little interest in working with China to combat the global public health crisis. Instead, a long list of U.S. government officials and lawmakers have accused Beijing of launching a "disinformation campaign" related to COVID-19 and of maneuvering the pandemic for economic and political advantages (Evans 2020; Miller 2020). There are also increasing calls to punish China for its alleged cover-up of the novel coronavirus (Rogin 2008). Against the backdrop of negative economic growth and massive unemployment caused by COVID-19, scapegoating China has quickly evolved to be a centerpiece of Trump's reelection campaign (Kumar 2020). As one prominent Chinese analyst put it, "COVID-19 has put a freeze on the China-U.S. relationship, highlighted serious deficit of mutual strategic trust, and resulted in unprecedented mutual bad feelings at the popular level" (Wang 2020).

Now that strategic competition has replaced engagement as U.S. policy toward China, what are the choices for Beijing?

It may continue to reassure Washington-both publicly and privately-of its commitment to a cooperative relationship, but such reassurances will most likely be dismissed as a deceptive tactic to hide China's strength and bide its time. Or it can demonstrate - through words and deeds-its deference to American leadership, which is out of the question against the backdrop of the great rejuvenation of the Chinese nation. For China's growing economic and military power has generated widespread aspirations for global leadership among its elites and citizens. Meanwhile, even if the White House has a new occupant in 2021, the new president might change the way in which strategic competition is implemented, but he is highly unlikely to reverse course on the Trump administration's China policy.

In the final analysis, it is time for Beijing to meet competition with competition. However, this essay does not focus on how Beijing should engage Washington competitively on which particular policy issues (e.g., Taiwan or trade) and at what level (bilateral or multilateral). Instead, it starts with the premise that China must compete with strength. As a Chinese saying goes, "to forge iron, one must be strong." Strength derives from not only economic resources and military capabilities, but also international legitimacy, as convincingly argued by David Lake (2018) in his 
analysis of America's post-World War II global leadership. Hence, this essay proposes four measures aimed at bolstering China's international legitimacy, namely, improving relations with its neighbors, enabling its prosperity to be more broadly shared, articulating attractive political values with Chinese characteristics, and making its national identity more inclusive. Put differently, these are self-strengthening measures that will make China more competitive, but not necessarily more confrontational vis-à-vis America.

The rise of the United States in the mid-nineteenth century coincided with the decline of the Middle Kingdom. The rise of China in the twenty-first century coincided with the relative decline of America, which remains the world's only superpower. When the great rejuvenation of the Chinese nation meets "Make America Great Again," strategic competition becomes inevitable. Fundamental differences in political institutions and values between the two great powers only add to the intensity of that competition.

Thus, the choice for Beijing and Washington is not whether to compete, but how. If the other is portrayed as a "useful adversary" for domestic political mobilization, then competition could quickly degenerate into confrontation, containment, or even conflict (Christensen 1996). However, if competition from the other is viewed as an opportunity to rally support for stalled domestic reform, then the two countries may avoid the tragedy of great power politics, at least in the short term (Mearsheimer 2001). If so, competition could be a win-win for both countries and the international community. It is up to leaders in Beijing and Washington to decide which approach they will adopt.

Acknowledgements The author is grateful to two anonymous reviewers for their comments. Guoxi Zhang at Sichuan International Studies University deserves special thanks for carefully reading each draft and offering suggestions for improvement. The author is solely responsible for the views expressed in the paper.

Funding This research is supported by a Young Faculty Research Grant of Beijing Foreign Studies University [2015JT003].

\section{References}

Dok, Akol Nyok Akol, Bradley A. Thayer. 2019. Takeover Trap: Why Imperialist China Is Invading Africa. National Interest. https://nationalinterest.org/feature/takeover-trap-why-imperialist-china -invading-africa-66421. Accessed 24 May 2020.

Acemoglu, Daron, and James Robinson. 2012. Why Nations Fail: The Origins of Power, Prosperity, and Poverty. New York: Crown Business.

BBC News. 2016. Africa-China Exports Fall by 40\% After China Slowdown. https://www.bbc.com/ news/world-africa-35303981. Accessed 24 May 2020.

Beijing News. 2017. More Chinese green cards should be issued (中国“绿卡”发放, 步子不妨迈大 点). https://epaper.bjnews.com.cn/html/2017-02/07/content_670318.htm?div=-1. Accessed 24 May 2020.

Blackwill, Robert, and Ashley J. Tellis. 2015. Revising U.S. Grand Strategy Toward China. Council on Foreign Relations. https://carnegieendowment.org/files/Tellis_Blackwill.pdf. Accessed 24 May 2020. 
Campbell, Kurt M, and Ely Ratner. 2018. The China Reckoning: How Beijing Defied American Expectations. Foreign Affairs 97 (2): 60-70.

China.com.cn. 2014. Press Conference for the Second Session of the 12th National People's Congress. https://www.china.com.cn/zhibo/zhuanti/2014lianghui/2014-03/07/content_31665839.htm. Accessed 24 May 2020.

Christensen, Thomas J. 1996. Useful Adversaries: Grand Strategy, Domestic Mobilization, and SinoAmerican Conflict, 1947-1958. Princeton: Princeton University Press.

Cote-Muñoz, Natalia. 2019. China's Green Investments Won't Undo Its Environmental Damage to Latin America. Council on Foreign Relations. https://www.cfr.org/blog/chinas-green-investments-wontundo-its-environmental-damage-latin-america. Accessed 24 May 2020.

Egan, Matt. 2015. These Nations Are Panicking with Gold and Copper Prices So Low. CNN Business. https://money.cnn.com/2015/07/31/investing/metal-prices-falling-emerging-markets/. Accessed 24 May 2020.

Evans, Zachary. 2020. National Security Council Ties China's Expulsion of American Reporters to Coronavirus Outbreak. National Review. https://www.nationalreview.com/news/coronavirus-nationalsecurity-council-criticizes-china-expulsion-american-reporters/. Accessed 24 May 2020.

Fukuyama, Francis. 1992. The End of History and the Last Man. New York: Free Press.

Gamache, Lauren, Alexander Hammer, and Lin Jones. 2013. China's Trade and Investment Relationship with Africa. United States International Trade Commission. https://www.usitc.gov/publicatio ns/332/2013-04_China-Africa\%28GamacheHammerJones\%29.pdf. Accessed 24 May 2020.

Gerstel, Dylan. 2018. It's a (Debt) Trap! Managing China-IMF Cooperation Across the Belt and Road. Center for Strategic and International Studies. https://www.csis.org/npfp/its-debt-trap-managingchina-imf-cooperation-across-belt-and-road. Accessed 24 May 2020.

Giovannini, Matteo. 2020. China's proposal of a revised permanent residence law for foreigners is causing debate. CGTN. https://news.cgtn.com/news/2020-03-04/China-s-proposal-of-a-revised-perma nent-residence-law-for-foreigners-OAHzLs2pzi/index.html. Accessed 24 May 2020.

Huang, Kristin, and Alice Yan. 2018. New immigration bureau set up to handle growing number of foreigners in China. South China Morning Post. https://www.scmp.com/news/china/policies-politics/ article/2137058/new-immigration-bureau-set-handle-growing-number. Accessed 24 May 2020.

Japan Center for International Exchange. 2004. ASEAN-Japan Cooperation: A Foundation for East Asian Community. Tokyo: Japan Center for International Exchange.

Johnson, Keith, and Robbie Gramer. 2020. The Great China-U.S. Economic Decoupling. Foreign Policy. https://foreignpolicy.com/2020/05/14/china-us-pandemic-economy-tensions-trump-coronaviru s-covid-new-cold-war-economics-the-great-decoupling/. Accessed 24 May 2020.

Kharpal, Arjun. 2020. China's plans to ease its 'green card' rules for foreigners spark racist backlash online. CNBC. https://www.cnbc.com/2020/03/13/china-permanent-residency-proposal-racist-backl ash-spills-onto-twitter.html. Accessed 24 May 2020.

Kumar, Anita. 2020. Trump says blame China. His supporters are listening. Politico. https://www.polit ico.com/news/2020/05/03/trump-supporters-china-226309. Accessed 27 May 2020.

Lai, Karen P.Y., Shaun Lin, and James D. Sidaway. 2020. Financing the Belt and Road Initiative (BRI): research agendas beyond the 'debt-trap' discourse. Eurasian Geography and Economics 61 (2): $109-124$.

Lake, David A. 2018. International Legitimacy Lost? Rule and Resistance When America Is First. Perspectives on Politics 16 (1): 6-21.

Llewelyn, James. 2014. Japan's Cold War Diplomacy and its Return to Southeast Asia. Asia-Pacific Review 21 (2): 86-116.

McCurry, Justin, and Julia Kollewe. 2011. China overtakes Japan as world's second-largest economy. The Guardian. https://www.theguardian.com/business/2011/feb/14/china-second-largest-economy. Accessed 24 May 2020.

Mead, Walter Russell. 2018. Left and Right Agree: Get Tough on China. Wall Street Journal. https:// www.wsj.com/articles/left-and-right-agree-get-tough-on-china-1515458432. Accessed 24 May 2020.

Mearsheimer, John. 2001. The Tragedy of Great Power Politics. New York: Norton.

Miller, Maggie. 2020. House Republican urges Pompeo to take steps to limit misinformation from China on coronavirus. The Hill. https://thehill.com/policy/cybersecurity/489898-house-republican-urges -pompeo-to-take-steps-to-limit-coronavirus-misinformation. Accessed 24 May 2020.

Ministry of Foreign Affairs of Japan. 2019. Towards Free and Open Indo-Pacific. https://www.mofa. go.jp/files/000407643.pdf. Accessed 24 May 2020. 
National Bureau of Statistics of China. 2011. Communiqué of the National Bureau of Statistics of People' s Republic of China on Major Figures of the 2010 Population Census (No. 1) (2010年第六次全国 人口普查主要数据公报(第1号)). https://www.stats.gov.cn/tjsj/tjgb/rkpcgb/qgrkpcgb/201104/t2011 0428_30327.html. Accessed 24 May 2020.

National Endowment for Democracy. 2017. China's Foreign Influence and Sharp Power Strategy to Shape and Influence Democratic Institutions. https://www.ned.org/wp-content/uploads/2017/12/ Sharp-Power-Rising-Authoritarian-Influence-Full-Report.pdf. Accessed 24 May 2020.

Nye Jr., Joseph S. 2004. Soft Power: The Means to Success in World Politics. New York: Public Affairs.

Nye Jr., Joseph S. 2008. Public Diplomacy and Soft Power. Annals of the American Academy of Political and Social Science 616 (1): 94-109.

Patrick, Stewart M. 2012. Why Natural Resources Are a Curse on Developing Countries and How to Fix It. The Atlantic. https://www.theatlantic.com/international/archive/2012/04/why-natur al-resources-are-a-curse-on-developing-countries-and-how-to-fix-it/256508/. Accessed 24 May 2020.

Reuters. 2013. China overtakes US as world's largest trading country. https://www.rt.com/business/ china-us-largest-trading-country-908/. Accessed 17 April 2018.

Rogin, Josh. 2020. The coronavirus crisis is turning Americans in both parties against China. Washington Post. https://www.washingtonpost.com/opinions/2020/04/08/coronavirus-crisis-is-turni ng-americans-both-parties-against-china/. Accessed 24 May 2020.

Shambaugh, David. 2017. Dealing with China: Tough Engagement and Managed Competition. Asia Policy 23: 4-12.

Sorace, Stephen. 2020. Protesters rally against Oregon's coronavirus stay-at-home order: 'It's our right to work'. Fox News. https://www.foxnews.com/us/oregon-protesters-coronavirus-stay-athome-order-lockdown. Accessed 24 May 2020.

The PRC State Council Information Office. 2014. White Paper on China's Foreign Aid (《中国的 对外援助(2014)》白皮书). https://www.scio.gov.cn/zfbps/ndhf/2014/Document/1375014/13750 14.htm. Accessed 24 May 2020.

Sukma, Rizal, and Yoshihide Soeya. 2015. Navigating Change: ASEAN-Japan Strategic Partnership in East Asia and in Global Governance. Tokyo: Japan Center for International Exchange.

$\mathrm{Su}$, Xiaochen. 2017. Why Chinese Infrastructure Loans in Africa Represent a Brand-New Type of Neocolonialism. The Diplomat. https://thediplomat.com/2017/06/why-chinese-infrastructural -loans-in-africa-represent-a-brand-new-type-of-neocolonialism/. Accessed 24 May 2020.

U.S. Department of Commerce. 2020. Export Administration Regulations: Amendments to General Prohibition Three (Foreign-Produced Direct Product Rule) and the Entity List. Federal Register. https://www.federalregister.gov/documents/2020/05/19/2020-10856/export-administrationregulations-amendments-to-general-prohibition-three-foreign-produced-direct. Accessed 24 May 2020.

U.S. Department of Defense. 2018. Summary of the 2018 National Defense Strategy of the United States of America. https://dod.defense.gov/Portals/1/Documents/pubs/2018-National-Defense-StrategySummary.pdf. Accessed 24 May 2020.

U.S. Department of Defense. 2019. Indo-Pacific Strategy Report: Preparedness, Partnerships, and Promoting a Networked Region. https://media.defense.gov/2019/Jul/01/2002152311/-1/-1/1/DEPAR TMENT-OF-DEFENSE-INDO-PACIFIC-STRATEGY-REPORT-2019.PDF. Accessed 24 May 2020.

U.S. Department of Justice. 2019. Chinese Telecommunications Conglomerate Huawei and Huawei CFO WanzhouMeng Charged With Financial Fraud. https://www.justice.gov/opa/pr/chinese-telecommun ications-conglomerate-huawei-and-huawei-cfo-wanzhou-meng-charged-financial. Accessed 24 May 2020.

Wang, Jisi [王缉思]. 2020. China-U.S. Relations in Light of COVID-19 (新冠疫情下的中美关系). The Paper. https://www.thepaper.cn/newsDetail_forward_6868297. Accessed 24 May 2020.

Wang Yi [王毅]. 2018. Press Conference for the First Session of the 13th National People's Congress (十三届全国人大一次会议记者会). The National People's Congress of the People's Republic of China (中国人大网). https://www.npc.gov.cn/zgrdw/npc/zhibo/zzzb37/node_9634.htm. Accessed 24 May 2020.

White House. 2017. National Security Strategy of the United States of America. https://www.whitehouse .gov/wp-content/uploads/2017/12/NSS-Final-12-18-2017-0905.pdf. Accessed 24 May 2020. 
White House. 2020. United States Strategic Approach to The People's Republic of China. https://www. whitehouse.gov/wp-content/uploads/2020/05/U.S.-Strategic-Approach-to-The-Peoples-Republic-ofChina-Report-5.20.20.pdf?from=timeline\&isappinstalled=0. Accessed 24 May 2020.

World Bank. 2018a. World Development Indicators. https://data.worldbank.org/indicator. Accessed 17 Apr 2018.

World Bank. 2018b. China: Systematic Country Diagnostic, Towards a More Inclusive and Sustainable Development. https://documents.worldbank.org/curated/en/147231519162198351/China-Syste matic-Country-Diagnostic-towards-a-more-inclusive-and-sustainable-development. Accessed 24 May 2020.

Xie, Tao, and Benjamin I. Page. 2013. What Affects China's International Image? A Cross-national Study of Public Opinion. Journal of Contemporary China 22 (82): 850-867.

Xi, Jinping. 2013. 'Promote Friendship Between Our People and Work Together to Build a Bright Future,' Speech at Nazarbayev University, Astana. Ministry of Foreign Affairs of the People's Republic of China. https://www.fmprc.gov.cn/mfa_eng/wjdt_665385/zyjh_665391/t1078088.shtml. Accessed 24 May 2020.

Xinhua News Agency. 2018a. China Focus: China's economy on firm footing, stronger growth engine for world. https://www.xinhuanet.com/english/2018-02/28/c_137006463.htm. Accessed 17 Apr 2018.

Xinhua News Agency. 2018b. Full text of Chinese President Xi Jinping's speech at opening ceremony of 2018 FOCAC Beijing Summit. https://www.xinhuanet.com/english/2018-09/03/c_129946189.htm. Accessed 24 May 2020.

Zhang, Monna. 2015. China will remain the largest contributor to global growth. CNTV. https://engli sh.cntv.cn/2015/01/12/ARTI1421055163823218.shtml. Accessed 17 Apr 2018.

Zhang,Yan. 2018. New immigration department set up. China Daily. https://usa.chinadaily.com. cn/a/201804/03/WS5ac2be41a3105cdcf6515d6b.html. Accessed 24 May 2020.

Zhao, Minghao. 2019. Is a New Cold War Inevitable? Chinese Perspectives on US-China Strategic Competition. The Chinese Journal of International Politics 12 (3): 371-394. https://doi.org/10.1093/cjip/ poz010.

Zhao, Suisheng. 2017. American Reflections on the Engagement with China and Responses to President Xi's New Model of Major Power Relations. Journal of Contemporary China 106 (26): 489-503. 